\title{
Correction to: Effectiveness of a digitally supported care management programme to reduce unmet needs of family caregivers of people with dementia: study protocol for a cluster randomised controlled trial (GAIN)
}

Olga A. Klein ${ }^{1 *+}$, Melanie Boekholt ${ }^{2 \dagger}$, Dilshad Afrin ${ }^{2}$, Christina Dornquast ${ }^{2}$, Adina Dreier-Wolfgramm ${ }^{5}$, Armin Keller $^{6}$, Bernhard Michalowsky², Ina Zwingmann ${ }^{4}$, Stefan Teipel ${ }^{1,3}$, Jochen René Thyrian ${ }^{2,7}$, Ingo Kilimann ${ }^{1,3}$ and Wolfgang Hoffmann ${ }^{2,7}$

Correction to: Trials 22, 401 (2021) https://doi.org/10.1186/s13063-021-05290-w

Following the publication of the original article [1], we were notified that the affiliations for some of the authors dementia: study protocol for a cluster randomised controlled trial (GAIN). needed amendment.

The original article has been corrected.

\begin{abstract}
Author details
${ }^{1}$ German Center for Neurodegenerative Diseases (DZNE), site Rostock/ Greifswald, Rostock, Germany. ${ }^{2}$ German Center for Neurodegenerative Diseases (DZNE), site Rostock/Greifswald, Greifswald, Germany. ${ }^{3}$ Department for Psychosomatic and Psychotherapeutical Medicine, University Hospital Rostock, Rostock, Germany. ${ }^{4}$ European University of Applied Sciences (EU FH), Rostock, Germany. ${ }^{5}$ Hamburg University of Applied Sciences (HAW), Faculty of Business and Social Sciences, Department of Nursing and Management, Hamburg, Germany. ${ }^{6}$ Institute of Medical Psychology and Medical Sociology, Medical Faculty, University of Rostock, Rostock, Germany. ${ }^{7}$ Institute for Community Medicine, Section Epidemiology and Community Health, University Medicine Greifswald, Greifswald, Germany.
\end{abstract}

Published online: 06 July 2021

\section{Reference}

1. Klein, et al. Effectiveness of a digitally supported care management programme to reduce unmet needs of family caregivers of people with

\footnotetext{
The original article can be found online at https://doi.org/10.1186/s13063021-05290-w.

*Correspondence: olga.klein@dzne.de

${ }^{\dagger}$ Olga A. Klein and Melanie Boekholt contributed equally to this work.

'German Center for Neurodegenerative Diseases (DZNE), site Rostock/ Greifswald, Rostock, Germany

Full list of author information is available at the end of the article
}

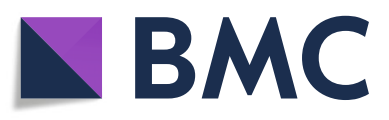

๑ The Author(s). 2021 Open Access This article is licensed under a Creative Commons Attribution 4.0 International License, which permits use, sharing, adaptation, distribution and reproduction in any medium or format, as long as you give appropriate credit to the original author(s) and the source, provide a link to the Creative Commons licence, and indicate if changes were made. The images or other third party material in this article are included in the article's Creative Commons licence, unless indicated otherwise in a credit line to the material. If material is not included in the article's Creative Commons licence and your intended use is not permitted by statutory regulation or exceeds the permitted use, you will need to obtain permission directly from the copyright holder. To view a copy of this licence, visit http://creativecommons.org/licenses/by/4.0/. The Creative Commons Public Domain Dedication waiver (http://creativecommons.org/publicdomain/zero/1.0/) applies to the data made available in this article, unless otherwise stated in a credit line to the data. 